УДК: 004.85:811.111:81’42

Драч Анна Сергї̈вна

старший викладач кафедри іноземних мов професійного спрямування

Запорізький національний університет, м. Запоріжжя, Україна

ORCID ID 0000-0002-5086-5331

annadrach2017@gmail.com

\title{
ТЕХНОЛОГІЯ РОЗРОБЛЕННЯ ПРОГРАМНИХ ПРОДУКТІВ ДЛЯ НАВЧАННЯ ЧИТАННЯ ХУДОЖНІХ ТЕКСТІВ (НА ПРИКЛАДІ «ЕNGLISH FOR PHILOLOGISTS: ASPECT OF READING»)
}

\begin{abstract}
Анотація. У статті розглядається питання створення навчальної комп'ютерної програми: етапи, блоки, аспекти й особливості. Надається визначення навчальної комп'ютерної програми як засобу інформаційно-комунікаційних технологій, створеного для формування навичок i вмінь іншомовної компетентностіз урахуванням психолінгвістичних закономірностей читання тексту, методичних можливостей навчання 3 використанням інформаційно-комунікаційних технологій. Було визначено, що навчальну комп'ютерну програму як програмний засіб навчального призначення можна запропонувати у вигляді системи, що складається 3 двох основних компонентів: інформаційного та програмного. Встановлено, що створення навчальних комп'ютерних програм, придатних для використання у навчальних закладах, це процес постійної взаємодії автора навчальних матеріалів та програміста. Технологія створення якісної навчальної комп'ютерної програми включає певні етапи: підготовку вихідних матеріалів; розробку програмної структури; створення програмного продукту; налагодження і коректування; реалізацію навчальної комп'ютерної програми; апробацію програмного продукту; вдосконалення навчальної комп'ютерної програми та виправлення помилок. У статті описано створену навчальну комп'ютерну програму «English for Philologists: aspect of reading», яка відповідає критеріям відповідності та критеріям оцінки комп'ютерних програм для навчання іноземній мові 3 урахуванням особливостей електронного тексту. Експериментальне впровадження навчальної комп'ютерної програми “English for Philologists: aspect of reading”, порівняння середніх показників перед- і після експериментального зрізів у експериментальних групах та приросту (12\%) показало, що навчання майбутніх учителів англійської мови читання художнього тексту за методикою з використанням навчальної комп'ютерної програми «English for Philologists: aspect of reading» виявилось ефективним: усі групи досягли необхідного рівня сформованості вмінь читання.
\end{abstract}

Ключові слова: навчальна комп'ютерна програма; тестування програмного продукту; інформаційний та програмний компонент.

\section{1. ВСТУП}

Постановка проблеми. Європейський контекст розвитку освіти в Україні посилює увагу суспільства до якості іншомовного навчання. Модернізація вищої освіти в контексті Європейських вимог надає нового значення практичному володінню іноземною мовою (IM) студентів-філологів. Сучасні умови вимагають нових підходів до освітніх технологій. Вирішення цього питання можливо при залученні інформаційно-комунікаційних технологій (IКТ) освітнього призначення, зокрема навчальної комп’ютерної програми (НКП), спрямованої на формування у майбутніх учителів IM умінь читання художніх текстів (XT).

Спираючись на досвід попередників, ми визначаємо НКП для навчання читання як засіб IKT, створений для формування іншомовної компетентності з урахуванням психолінгвістичних закономірностей читання тексту, методичних можливостей навчання з використанням IКT. 
Аналіз останніх досліджень. Питанню створення НКП та інших електронних засобів навчання ІМ приділяється велика увага вітчизняних і зарубіжних дослідників. Існують різні точки зору щодо технології створення НКП. Згідно 3 першою, кваліфікований програміст може взяти будь-який традиційний навчальний посібник та без допомоги його автора або методиста створити навчальну комп'ютерну програму [9]. У цьому випадку абсолютизується програмний компонент. Результат може бути незадовільним, тому що навіть при отриманні високоякісного програмного продукту та використанні найновіших досягнень мультимедіа в багатьох випадках НКП не відповідає методичним вимогам до навчальних матеріалів з IM [3],[5],[6],[7], [9], [10], [11],[12], [13], [16], [18],[19].

Інша точка зору абсолютизує роль автора навчальних матеріалів, який створює інформаційний компонент програми. Викладач IM готує необхідні навчальні матеріали та за допомогою створених останнім часом інструментальних програмних засобів розробки навчальних комп'ютерних модулів самостійно створює програмний продукт, тобто наповнює «оболонку» необхідним лексичним i/aбо граматичним, текстовим матеріалами. У перспективі цей метод створення НКП можливо здобуде розповсюдження. Але зараз, навіть при комп'ютеризації закладів вищої і середньої освіти та постійно зростаючій комп'ютерній грамотності викладачів, автори-викладачі навчальних дисциплін не мають достатньої кваліфікації для створення НКП на професійному рівні. Інструментальні засоби розробки за своїми функціональними можливостями значною мірою поступаються засобу сучасного програмування, тому що недооцінюють можливості комп'ютерів, зокрема, в аналізі повідомлень студентів [10, c. 44]. Як переоцінка, так і недостатня оцінка ролі автора-викладача або програміста у створенні НКП призводить до появи програм, які не зовсім відповідають меті, завданням та умовам вивчення IM на конкретному етапі певним контингентом студентів; не відображають головні дидактичні та методичні принципи навчання IM; не використовують усі технічні та дидактичні можливості комп'ютерного навчання IM; програм, які не є доступними, цікавими, а головне - не $\epsilon$ ефективними для вивчення IM. Тому створення НКП, придатних для використання у навчальних закладах, - це процес постійної взаємодії автора навчальних матеріалів та програміста [9].

Метою статті $\epsilon$ визначення основних етапів технології створення НКП, іiі структури, критеріїв ефективності, відповідності та оцінки.

\section{2. РЕЗУЛЬТАТИ ДОСЛІДЖЕННЯ}

А. Н. Романов виділяє такі фактори необхідності співпраці автора та програміста: 1) у процесі розробки (апробації, використання) НКП можуть з'явитися нові нормативні документи, виникнути зміни в навчальній програмі або з'явитися нова література, використання якої може значною мірою актуалізувати навчальний матеріал; 2) програміст, знаючи можливості програмних засобів, які він використовує, може наштовхнути автора на нові, оригінальні та ефективні форми надання інформації та контролю знань; 3) деякі специфічні складники НКП (наприклад, написання сценарію, складання алгоритму, корекція макету програми, апробація програмного продукту в навчальному процесі) повинні розроблятися та впроваджуватися тільки за умови тісної взаємодії автора-викладача та програміста [10, с. 45].

Серед критеріїв оцінки НКП виділяють критерії відповідності (критерії якості) НКП для навчання іноземної мови та критерії оцінки НКП з урахуванням особливостей електронного тексту. До перших відносять: сприяння підвищенню продуктивності праці й ефективності освітнього процесу; підвищення свідомості й інтересу до вивчення іноземної мови; оперативність зворотного зв'язку; можливість швидкого 
введення відповідей без тривалого кодування і шифрування; наявність тренувальних завдань; наявність контрольних завдань; реалізація навчальної функції інтерфейсу; комплексність дидактичних матеріалів; наявність супроводжувальної документації; можливість багаторазового виконання вправ; наявність наочності. До других: нелінійну структуру тексту; наявність «когезії» - поверхневої лінійної структури тексту як послідовного сполучення речень, але лише на рівні окремих текстів як складових; цілісність, «когерентність»- глибинну структуру тексту, у якій значення використаних у тексті мовних виразів семантично поєднані й зумовлені контекстом; інтенціональність - спрямованість на читача; інтертекстуальність - наявність у письмовому тексті великої кількості раніше створених текстів [9].

Критеріями оцінки НКП для навчання читання $\epsilon$ (Е. М. Бовтенко [3], Л. Н. Погорелова [8]) відповідність вимогам, що пред'являються до електронного тексту; використання комплексу засобів презентації матеріалу (звук, графіка, мультиплікація, відео, текст), максимальне використання аудіоформату, показ явищ у динаміці;наявність належної послідовності вправ, які формують відповідні навички і вміння в читанні, чітке розмежування тренувальних і контролюючих вправ; варіювання мовного наповнення завдань; оптимальна кількість та різноманітність типів вправ; ефективні засоби виконання завдань, традиційних для друкованих, аудіовідеоматеріалів; наявність специфічних комп'ютерних видів завдань, які складно або неможливо виконати без використання комп'ютера; можливість перегляду, аналізу, виправлення помилок; комплексність дидактичних матеріалів (залучення до структури словників, редакторів тексту); адаптивність навчальних матеріалів (можливість вибору рівня складності, обсягу, формату подання інформації: текстового, аудіо, відео і варіантів їх комбінування, послідовність виконання завдань, часу на їх виконання); можливість об' єктивно оцінити початковий і кінцевий рівень сформованості навичок і вмінь читання; можливість роботи в діалоговому режимі.

Прийнято виділяти такі основні етапи в технології створення НКП: підготовка вихідних матеріалів; розробка програмної структури НКП; створення програмного продукту; налагодження і коректування; реалізація НКП; апробація НКП; впровадження в навчальний процес [5].

Таблиия 1

Етапи технології створення НКП «English for Philologists: aspect of reading»

\begin{tabular}{|c|c|c|}
\hline № & Eтап & Мета \\
\hline 1. & $\begin{array}{l}\text { Підготовка вихідних } \\
\text { матеріалів }\end{array}$ & $\begin{array}{l}\text { Визначити: } \\
\text { - мету та завдання; } \\
\text { - зміст навчання; } \\
\text { - контингент студентів; } \\
\text { - місце курсу серед інших методів і засобів } \\
\text { навчання; } \\
\text { - одномовність/багатомовність курсу; } \\
\text { - технологію та технічні засоби навчання } \\
\end{array}$ \\
\hline 2. & $\begin{array}{l}\text { Розробка програмної } \\
\text { структури НКП }\end{array}$ & $\begin{array}{l}\text { Визначити: } \\
\text { - структуру НКП; } \\
\text { - (підсистему) систему вправ; } \\
\text { - форму взаємодії між викладачем та студентом; } \\
\text { - форму зворотного зв' язку та контроль. } \\
\end{array}$ \\
\hline 3. & $\begin{array}{l}\text { Створення програмного } \\
\text { продукту }\end{array}$ & $\begin{array}{l}\text { Скласти алгоритм окремих вправ та курсу загалом; } \\
\text { обрати програмні засоби }\end{array}$ \\
\hline
\end{tabular}




\begin{tabular}{|c|l|l|}
\hline 4. & $\begin{array}{l}\text { Налагодження і } \\
\text { коректування }\end{array}$ & $\begin{array}{l}\text { Здійснити корекцію змістовної частини НКП } \\
\text { методистом залежно від зауважень програміста }\end{array}$ \\
\hline 5. & Реалізація НКП & $\begin{array}{l}\text { Здійснити введення НКП у комп’ютер; } \\
\text { виправити синтаксичні, логічні, методичні та } \\
\text { лінгвістичні помилки в НКП }\end{array}$ \\
\hline 6. & Апробація & $\begin{array}{l}\text { Провести експериментальну перевірку та оцінку } \\
\text { ефективності НКП }\end{array}$ \\
\hline 7. & Впровадження НКП & $\begin{array}{l}\text { Відредагувати навчальні матеріали, сформувати } \\
\text { інструкції та здійснити остаточні доопрацювання } \\
\text { курсу;скласти техніко-методичну документацію для } \\
\text { використання НКП }\end{array}$ \\
\hline
\end{tabular}

Розробка НКП «English for Philologists: aspect of reading» здійснювалась нами за вказаними етапами. Розглянемо детальніше сценарій створення НКП «English for Philologists: aspect of reading».

Етап підготовки вихідних матеріалів є найскладнішим для автора-викладача IM. На цьому етапі було сформульовано мету й завдання курсу, відібрано навчальний матеріал, що відповідає меті навчання та контингенту студентів, а також проаналізовано ті специфічні вимоги, які висуває щодо навчального матеріалу саме комп'ютеризоване навчання IM.

На етапі підготовки ми дотримувались універсальних положень про створення ефективної навчальної програми, сформульованих I. M. Hefzallah [19, с. 32]. Відповідно до цих положень нами було: 1) визначено конкретну мету навчання - читання XT; 2) ідентифіковано групу студентів, яких заплановано для навчання - студенти-філологи, майбутні вчителі англійської мови та літератури, II курс; 3) визначено обсяг інформації;4) обрано відповідну технологію навчання, що увійшла до загальної системи навчання; 5) розроблено стратегію навчання згідно 3 викладеними вище положеннями.

Працюючи над розробкою НКП, ми спочатку вирішили загальні педагогічні питання, зокрема: доцільність використання комп'ютера для оволодіння навичками й вміннями вивчаючого та ознайомлювального читання, досвід i рівень підготовки студентів у читанні XT на II курсі та використанні комп'ютера, тривалість заняття і місця використання комп'ютерних матеріалів на занятті.

Важливою особливістю створеної нами НКП $\epsilon$ можливість використання розгалуженої системи допомоги користувачам та реалізація зворотного зв'язку. У НКП застосовується зорова допомога. Після виконання вправ студент натискає клавішу «Check». НКП передбачає такі засоби реагування на відповіді студентів:

1) повідомляє про правильність чи неправильність виконання вправи, вказує кількість правильних та неправильних відповідей;

2) у разі помилки надає кількість спроб виконання завдання (у деяких випадках кількість спроб фіксується);

3) подає підказки різних видів:у вигляді зазначення місця помилки; у вигляді варіантів правильної відповіді; у вигляді перекладу рідною мовою.

Існує три тенденції щодо одержання необхідних матеріалів: 1) підбір та використання доступних готових матеріалів,2) модифікація/вдосконалення існуючих матеріалів, 3) розробка нових матеріалів [7].

C. В. Радецька пропонує робити вибір із доступних готових матеріалів для застосування у навчальному процесі, виходячи із: 
- відповідності матеріалів меті курсу;

- відповідності матеріалів рівню мовної та мовленнєвої компетентності студентів;

- відповідності сучасності змісту й актуальності наведених програм;

- спроможності технічної і технологічної презентації;

- якості й ефективності матеріалів, які підтверджені попереднім досвідом їхнього використання [9].

До модифікації або вдосконалення матеріалів рекомендується звертатися у разі неможливості використання матеріалів в оригінальному вигляді. Це може бути спричинено невідповідністю мови, технічних засобів, технологій тощо [16, с. 49-50].

На цьому ж етапі визначається місце НКП серед інших методів і засобів навчання. Як було зазначено вище, тут існує два основних підходи. Перший передбачає використання НКП як доповнення до друкованих підручників та навчальних посібників, тобто НКП використовується викладачем разом з основним курсом мови. Другий підхід полягає в тому, що НКП створюється як самостійний комплексний навчальний засіб. За типологією П. І. Сердюкова, самостійна, завершена система навчання, яка містить весь необхідний набір компонентів: тексти, вправи, тести, довідковий матеріал (словник і граматика) і додатковий матеріал (тексти, вірші, пісні тощо), спрямований на досягнення певної навчальної мети, має назву «комп'ютерний» курс [11]. Найчастіше НКП складає лише частину загальної програми вивчення предмета, і цей факт слід враховувати на початку роботи над створенням НКП.

На етапі практичної розробки НКП було складено структурну схему всього курсу. У літературі, присвяченій комп'ютерному навчанню іноземних мов, розподіл навчальних матеріалів на невеликі закінчені частини прийнято називати розподілом на модулі [6, с. 231],[10, с. 53-54]. Необхідність чіткого структурування матеріалу (навіть більш жорсткого, ніж у традиційних підручниках) зумовлюється такими чинниками:

- організаційним - розбивка навчального матеріалу на блоки-модулі не тільки полегшує студенту вивчення цього матеріалу в режимі самостійної роботи 3 комп'ютером, а й дозволяє регламентувати порядок взаємодії студента з комп'ютером;

- функиіональним - реалізація гіпертекстових переходів під час розробки НКП повинна передбачати відособленість змістовних фрагментів тем [11, с. 54].

Структуру НКП «English for Philologists: aspect of reading» подано в таблиці 2.

Таблиия 2

\section{Структура НКП «English for Philologists: aspect of reading»}

\begin{tabular}{|c|c|c|}
\hline \multicolumn{3}{|c|}{ 1. ВСТУПНА ЧАСТИНА } \\
\hline \multicolumn{3}{|c|}{ Мета: інформаційно-організаційна } \\
\hline Block 1 & \multicolumn{2}{|c|}{ Відомості про НКП } \\
\hline Block 2 & \multicolumn{2}{|c|}{ Методичні рекомендації з вивчення навчального матеріалу } \\
\hline Block 3 & \multicolumn{2}{|c|}{ Пакет анкет } \\
\hline Block 4 & \multicolumn{2}{|c|}{ Пакет тестових завдань для визначення вхідного рівня вмінь } \\
\hline \multicolumn{3}{|c|}{ 2. ОСНОВНА ЧАСТИНА } \\
\hline \multicolumn{3}{|c|}{ Мета: навчально-тренувальна } \\
\hline \multirow{2}{*}{ Block 1} & \multicolumn{2}{|c|}{ Text $1 \ll$ A Deal of Paint»by Elizabeth Ayrton } \\
\hline & \begin{tabular}{|l|r} 
Pre-Reading & Reading \\
\end{tabular} & Post-Reading \\
\hline \multirow[t]{2}{*}{ Block 2} & \multicolumn{2}{|c|}{$\begin{array}{c}\text { Text } 2 \ll A \text { future businessman» (from «The Financier» by Theodore } \\
\text { Dreiser) }\end{array}$} \\
\hline & \begin{tabular}{|l|r} 
Pre-Reading & Reading \\
\end{tabular} & Post-Reading \\
\hline Block 3 & \multicolumn{2}{|c|}{ Text $3 \ll A$ Thousand Diseases» after Jerom K. Jerom } \\
\hline
\end{tabular}




\begin{tabular}{|c|c|c|c|}
\hline & \multicolumn{3}{|c|}{ «Three men in a Boat» } \\
\hline & Pre-Reading & Reading & Post-Reading \\
\hline \multirow{2}{*}{ Block 4} & \multicolumn{3}{|c|}{ Text 4 «London: The Biography» by Peter Ackroyd } \\
\hline & Pre-Reading & Reading & Post-Reading \\
\hline \multirow[t]{2}{*}{ Block 5} & \multicolumn{3}{|c|}{$\begin{array}{c}\text { Text 5«New Year's Resolutions» (from «Bridget Jones's Diary» by Helen } \\
\text { Fielding) }\end{array}$} \\
\hline & Pre-Reading & Reading & Post-Reading \\
\hline \multicolumn{4}{|c|}{ 3. ЗАКЛЮЧНА ЧАСТИНА } \\
\hline \multicolumn{4}{|c|}{ Мета: інформаційно-довідкова; практично-комунікативна } \\
\hline Block 1 & & Glossar & \\
\hline Block 2 & & Online reso & \\
\hline Block 3 & & Referenc & \\
\hline Block 4 & & Students an & \\
\hline
\end{tabular}

Згідно з даними таблиці 2, НКП «English for Philologists: aspect of reading» має три частини: вступну, основну i заключну. До вступної частини увійшли чотири інформаційні блоки: відомості про НКП (дата створення, автори, вимоги до програмного налаштування (операційної системи, процесора, програмного забезпечення, оперативної пам'яті)); методичні рекомендації з вивчення навчального матеріалу (етапи роботи з ХT, порядок виконання вправ, вказівки щодо виконання творчих завдань та завдань, які викладач буде перевіряти особисто (без підтримки комп'ютера)); пакет анкет для визначення особистого ставлення студентів до використання інформаційно-комунікаційних технологій навчання загалом та НКП для навчання читання ХT зокрема; пакет тестових завдань для визначення вихідного рівня вмінь читання XТ.

Основна частина містить п'ять інформаційних блоків, до яких увійшло п'ять художніх текстів, відповідно до п’яти тем практичних занять.

Відібрані для навчання читання з екрану монітору ХТ також відрізняються за рівнем складності за принципом від простішого до складнішого та за обсягом, наприклад: текст 1. «Fahrenheit 451»byRayBradbury обіймає 2 сторінки; текст 2. «А future businessman» (from «The Financier» by Theodore Dreiser) - 2,2 сторінки; текст 3 . «A Thousand Diseases» by Jerom K. Jerom «Three men in a Boat»-2,5 сторінки; текст 4. «London: The Biography» by Peter Ackroyd-2,6 сторінки;текст 5. «New Year's Resolutions» (from «Bridget Jones's Diary» by Helen Fielding)- 2,7 сторінки.

До заключної частини увійшли: «Glossary» - словник, якій містить лексичні одиниці, що зустрічаються у XТ; «Onlineresources»- перелік адрес сайтів, які містять ХТ та іншу інформацію, що увійшла до НКП; «References»- список використаних джерел інформації; «Studentsanswers» - банк, що містить письмові відповіді студентів.

Далі була створена підсистема вправ, спрямованих на формування навичок i вмінь вивчаючого та ознайомлювального видів читання ХТ, визначені форми взаємодії викладача зі студентами, вибрані форми зворотного зв'язку.

Студентам із самого початку роботи за комп'ютером було чітко повідомлено конкретну мету і завдання. Ознайомлюючись 3 ними, студенти розуміли кінцеву мету виконання курсу. Мета курсу загалом і кожного завдання окремо була орієнтована на студента (Student-Oriented-Instruction) [17],[20]. Зміст мав розкривати мету та призначення НКП для обраної аудиторії, був доречним, точним, перевіреним, повним і добре організованим, підкреслював нове i незнайоме, грунтуючись на загальних елементарних знаннях студентів. 
Ефективність НКП значною мірою залежить від роботи програміста на третьому етапі - етапістворення програмного продукту. На цьому етапі складався алгоритм НКП - чіткий опис взаємопов'язаних елементарних операцій, які відображають процес виконання студентом навчального завдання. Створена нами НКП «English for Philologists: aspect of reading» належить до комбінованого типу. Студент при взаємодії 3 комп'ютером самостійно здійснює вибір навчального матеріалу та може змінювати послідовність його проходження. Керування діяльністю студента 3 боку НКП реалізується шляхом надання правильних відповідей після закінчення виконання вправ; виконання підсистеми вправ здійснюється в наданій послідовності, що є логічним і раціональним з методичної та організаційної точки зору.

На цьому етапі також проходив вибір базових засобів розробки, зокрема, системи та мови програмування, засобів інформації. Засоби інформації - форми вираження змісту (текст, відео, звук, зображення), які повинні підтримувати навчальну мету [6]. М. Симмонсон зазначає, що вибір засобів інформації не має значного впливу на результати навчання, але може впливати на мотивацію навчання та термін виконання окремих завдань. На вибір засобів інформації впливає, з одного боку, наявність певних засобів, виправдання витрат на використання різних видів засобів, рівень умінь користувача, а 3 іншого боку, - можливість частково змінити навчальний діалог «студент - викладач» порівняно з традиційним навчанням [18, с. 45-51].

Далі визначався дизайн НКП, здійснювалась розробка інтерфейсу, створювалися навігаційні елементи та стандартні функціональні модулі (системи реєстрації, робота 3 базою даних). Елементи керування та меню - загальні засоби забезпечення навігаційного та функціонального контролю НКП користувачем. Засоби навігації повинні бути легко доступними та зрозумілими студенту. Ними служать меню, панелі інструментів, гіпертекстові посилання, засоби перегляду тексту. Вони використовуються для переміщення на наступну сторінку, повернення на попередню, вихід з НКП, повернення до початку, звернення до довідки. Меню повинно мати ясні та значущі позначення. Користувачі повинні бути захищені від появи помилок типу несанкціонованого закінчення з втратою даних або «зависання». Вертикальний ліфтінг (скролінг/смуга прокручування може вказувати положення на окремій сторінці НКП, але не для всієї НКП.

Особливі вимоги висуваються до стилю оформлення курсу. Характеристики типу i розміру шрифту можуть значно впливати на якість інформації в НКП. Слід використовувати найбільш розповсюджений тип шрифту (TimesNewRoman). Обсяг матеріалу на екрані має бути невеликим (те, що вміщується в кадр) [18, с. 45-51]. Необхідно вилучати, наскільки можливо, непотрібні слова, роблячи текст компактним. Занадто багато матеріалу, велика кількість рамок зумовлюють хаотичний зовнішній вигляд, відвертають увагу від основної інформації. Повинні використовуватися методи привертання уваги до важливої інформації. Це може бути виділення альтернативним кольором або курсивом активних блоків, а блідим кольором - неактивних блоків тощо. Колір та інші засоби подання на екрані повинні забезпечувати естетичний зовнішній вигляд курсу. Червоний та синій кольори $є$ найважчими для сприйняття, i їх бажано уникати як у тексті, так і в зображенні. Слід уникати також використання понад семи кольорів [6].

Тут необхідно зазначити, що згідно з дослідженнями В. Н. Акентьєвої, управління процесом розуміння передбачає формування вмінь орієнтуватися в ХT, бачити та виявляти різноманітні опори для розуміння, диференціювати інформацію за різними ознаками. Орієнтувальна діяльність під час читання здійснюється на всіх рівнях смислових одиниць тексту: реченнях, абзацах, завершених (цілісних) текстах. Формування вмінь орієнтуватися в тексті здійснюється за допомогою використання 
засобів управління, які за класифікацією дослідниці поділяються на перцептивні (різноманітні шрифти, колір, підкреслення) та змістові (правила, коментарі, примітки, денотатні графи, завдання на інтерпретацію) [1].

Використання цих засобів управління $є$ більш ефективним у застосуванні можливостей комп'ютерних технологій. Застосування текстового редактора в підготовці вихідних матеріалів для читання та під час самого читання дозволяє легко використовувати різні шрифти, курсив, підкреслення, колір для акцентування найбільш важливих за змістом місць у тексті: тематичних/ключових слів, речень, що дозволяє привернути й утримати увагу студентів. Використання гіперпосилань дає можливість створити розгалужену систему довідок на формально-мовному рівні (рівні значення). Графічні можливості комп'ютерних програм дозволяють не тільки робити та вставляти в текстові матеріали графіки та схеми, а вносити зміни та доповнення у процесі читання. Важливо зазначити, що ефект від використання різноманітних засобів управління досягається тільки за умови, коли вони не заважають розумінню текстів, як, наприклад, це можливо під час читання вже «опрацьованої» книги 3 читацькими позначками та виділеннями. Під час застосування комп'ютера можливість виникнення цього недоліку повністю усувається, тому що викладач має змогу легко, за рахунок використання буферів обміну та збереження інформації, переробляти матеріали для кожної групи та навіть кожного студента.

Наступним етапом є налагодження $i$ коректування. Погано виконаний дизайн може бути причиною стресу і втоми, які знижують у студентів бажання працювати або навчатися. Існують певні вимоги до інтерфейсу.

1. Програма має бути націлена на основну мету навчання.

2. Програма має бути легкою для використання.

3. Система повинна надавати інформацію у форматі i темпі, зручними для користувача.

4. Необхідно враховувати принципи ергономіки.

5. Помилковим $є$ твердження, що велика кількість графіки робить програму досконалішою.

6. Існують стандарти на підготовку друкованої продукції для комп'ютерних навчальних програм. Шрифт не повинен бути дуже жирним або дуже тонким, він має бути зручним для читання. Найбільш сприятливим є чорний шрифт на білому фоні або чорний на світлих кольорових фонах [2],[4].

На етапі реалізації НКП вводилася в комп'ютер. Робилося сканування, форматування текстових матеріалів, розробка графічних та відеоматеріалів. Аналіз існуючих курсів і програм свідчить про широке використання мультимедіа - технічних засобів, що дозволяють об'єднати в комп'ютерному середовищі текст, звук, графіку, мультиплікацію та відеозображення. Широке використання засобів мультимедіа у навчанні загалом, та IM зокрема, зумовлено можливостями мультимедійного середовища імітувати і моделювати реальні комунікативні ситуації й вирішувати різноманітні навчальні завдання проблемного характеру [13].

На етапі апробачіï НКП «English for Philologists: aspect of reading» спочатку тестувалася розробниками, а потім студентами. Було виправлено всі виявлені недоліки, була складена техніко-методична документація на НКП, яка містить у собі опис мети, структури та змісту НКП, посібник для користувача й методичні рекомендації для викладача. Будь-який викладач повинен мати можливість швидко оцінити зміст програми і визначити, чи відповідає вона певній навчальній меті. НКП також має містити дату розробки, щоб надати користувачам можливість робити висновки про відповідність змісту сучасному етапу. Уся необхідна документація створювалася у 
співавторстві розробників для уникнення розбіжностей у використанні комп’ютерної та методичної термінології.

Після отримання позитивних рекомендацій ми перейшли до етапу впровадження НКП в освітній процес. Вона застосовувалася згідно зісвоїм призначенням (на філологічних факультетах ВНЗ, на II курсі навчання).

Експериментальне впровадження НКП "English for Philologists: aspect of reading" проводилося на базі Запорізького національного університету у чотирьох експериментальних групах із загальною кількістю студентів 41 протягом 2016-2017 року. Напередодні, проводився передекспериментальний зріз, який дозволив зробити висновки про готовність студентів до проведення основного експерименту. Експеримент охоплював три етапи (передекспериментальний, експериментальний, післяекспериментальний), кожен з яких мав цільове призначення. Порівняння середніх показників перед- і післяекспериментального зрізів у експериментальних групах та приросту (12\%) свідчить про те, що навчання майбутніх учителів англійської мови читання художнього тексту за методикою 3 використанням НКП "English for Philologists: aspect of reading” виявилось ефективним: усі групи досягли необхідного рівня сформованості вмінь читання.

\section{3. ВИСНОВКИ ТА ПЕРСПЕКТИВИ ПОДАЛЬШИХ ДОСЛІДЖЕНЬ}

У результаті створення НКП «English for Philologists: aspect of reading» ми дійшли поданих нижче висновки.

1. Створення НКП, придатних для використання у навчальних закладах, - це процес постійної взаємодії автора-методиста, програміста, системного архітектора, дизайнера, тестувальника, оператора тощо. Як переоцінка, так і недооцінка їхньої ролі у створенні НКП може призвести до появи неякісного програмного продукту, який не відповідає меті, завданням та умовам вивчення IM на конкретному етапі певним контингентом студентів; не відображають головні дидактичні та методичні принципи навчання IM; не використовує всі технічні та дидактичні можливості комп'ютерного навчання IM; не є доступними, цікавими, а головне - не $є$ ефективними для вивчення IM.

2. Створена НКП «English for Philologists: aspect of reading» відповідає критеріям відповідності НКП для навчання іноземній мові та критеріям оцінки НКП 3 урахуванням особливостей електронного тексту.

3. Процес створення якісної НКП включає певні етапи: підготовку вихідних матеріалів; розробку програмної структури НКП; створення програмного продукту; налагодження і коректування; реалізацію НКП; апробацію програмного продукту; вдосконалення НКП та виправлення помилок.

Перспективою подальшого дослідження вважаємо створення і апробацію НКП для навчання інших видів мовленнєвої діяльності.

\section{СПИСОК ВИКОРИСТАНИХ ДЖЕРЕЛ}

[1] В. Н. Акентьева, "Управление процессом понимания текстов по специальности при обучении чтению в неязыковом вузе (на материале английского языка", дис. канд. пед. наук, КГПИИЯ, Киев, 1986.

[2] Н. В. Басова, Педагогика и практическая психология. Ростов-на-Дону, Россия: Феникс, 2000.

[3] М. А. Бовтенко, Компьютерная лингводидактика: [учебное пособие]. Москва, Россия: Флинта, 2005. 
[4] О. Я. Коваленко, та І.П.Кудіна, Книга вчителя іноземної мови:довідково-методичне видання. [вид. 2-ге, доповн.].Харків, Україна: ТОРСІНГ ПЛЮС, 2006.

[5] О. С. Красовський,"Дидактичні засади конструювання електронного підручника 3 природничих предметів для старшої школи загальноосвітніх навчальних закладів",автореф. дис. канд. пед. наук, Київ, 2013.

[6] В. М. Кухаренко, О. В Рибалко, та Н. Г. Сиротенко, Дистанційне навчання: Умови застосування. Дистаниійний курс: Навчальний посібник. 3-є вид. Харків, Україна: НТУ «ХПІ», «Торсінг», 2002.

[7] Н. I. Муліна, "Методика розробки та використання дистанційного курсу англійської мови»"дис. канд. пед. наук, Київ, 2001.

[8] Л. Н. Погорелова,"Создание текста в компьютерной среде",автореф. дис.канд. филол. наук, Москва, 1993.

[9] С. В. Радецька, "Методика навчання майбутніх економістів професійно спрямованого читання англійською мовою з використанням комп’ютера", дис. канд. пед. наук, Київ, 2004.

А. Н. Романов, В. С. Горонцов, и Д. Б. Григорович, Технология дистанциионого образования в системе заочного экономического образования. Москва, Россия: ЮНИТИ - ДАНА, 2000.

[11] П. И. Сердюков, "Теоретические основы обучения иностранным языкам в языковом вузе с применением информационных технологий",дис. д-ра пед. наук, Киев, 1997.

[12] О.Б.Бігич, та ін.,Теорія $i$ практика формування іншомовної професійноорієнтованої компетентності в говорінні у студентів нелінгвістичних спеціальностей. Колективна монографія.Київ, Україна: Вид. центр КНЛУ, 2013.

[13] J. Colomen,"Interactive Multimedia",Computers as a Tool in Language Teaching. N.Y., USA: EleisHorwood,pp. 87-111, 1991.

[14] R.C.Scarcella, E.S. Anderson, andS.D. Krashen, Developing Communicative Competence in a Second Language.Boston, USA: Heinle and Heinle Publishers, a division of Wadsworth, Inc., 1990.

[15] P. Dunkel,"The Effect of CAI on ESL Reading Achievement",CALL Digest, vol. 4(1), pp. 253-261, 1988.

[16] R.Heinich, M.Molemda,and J.D.Russel,Instructional Media and the New Technologies of Instruction. N.Y., USA: Macmillan Publishing Company, 1993.

[17] T. Hutchinson, andA. Waters,English for Specific Purposes: A Learner-Centered-Approach. Cambridge, USA: CambridgeUniversity Press, 1987.

[18] M.Simonson, andA.Thompson, Educational Computing Foundations.New-York, USA: MacMillan College Publishing Company, 1994.

[19] I.M. Hefzallah,The New Learning and Telecommunications Technologies. Their Potential. Springfield, Illinois, USA: Charles C. Thomas Publisher, 1990.

[20] Z. Voronka,"Active Methods of Teaching Spoken English",Іноземні мови, vol. 2, pp. 3-5, 1995.

Матеріал надійшов до редакиіï 27.02.2018 p.

\title{
ТЕХНОЛОГИЯ РАЗРАБОТКИ ПРОГРАММНЫХ ПРОДУКТОВ ДЛЯ ОБУЧЕНИЯ ЧТЕНИЮ ХУДОЖЕСТВЕННЫХ ТЕКСТОВ (НА ПРИМЕРЕ "ENGLISH FOR PHILOLOGISTS: ASPECT OF READING")
}

\author{
Драч Анна Сергеевна \\ старший преподаватель кафедры иностранных языков профессионального направления \\ Запорожский национальный университет, г. Запорожье, Украина \\ ORCID ID 0000-0002-5086-5331 \\ annadrach2017@gmail.com
}

\begin{abstract}
Аннотация. В статье рассматривается процесс создания обучающей компьютерной программы: этапы, блоки, аспекты и особенности. Дается определение обучающей компьютерной программы как средства информационно-коммуникационных технологий, созданного для формирования навыков и умений иноязычной компетентности с учетом психолингвистических закономерностей чтения текста, методических возможностей обучения с использованием информационно-коммуникационных технологий.

Было определено, что обучающую компьютерную программу как программное средство учебного назначения можно предложить в виде системы, состоящей из двух основных компонентов: информационного и программного. Установлено, что создание обучающих
\end{abstract}


компьютерных программ, пригодных для использования в учебных заведениях, это процесс постоянного взаимодействия автора учебных материалов и программиста. Процесс создания качественной обучающей компьютерной программы включает определенные этапы: подготовку исходных материалов; разработку программной структуры; создание программного продукта; наладки и корректировки; реализацию учебной компьютерной программы; апробацию программного продукта; совершенствование учебной компьютерной программы и исправления ошибок. В статье описано созданную обучающую компьютерную программу «English for Philologists: aspect of reading», которая отвечает критериям соответствия и критериям оценки компьютерных программ для обучения иностранному с учетом особенностей электронного текста. Экспериментальное внедрение обучающей компьютерной программы «English for Philologists: aspect of reading», сравнение средних показателей пред- и после экспериментального срезов в экспериментальных группах и прироста (12\%) показало, что обучение будущих учителей английского языка чтения художественного текста методике с использованием учебной компьютерной программы «English for Philologists: aspect of reading» оказалось эффективным: все группы достигли необходимого уровня сформированности умений чтения.

Ключевые слова: обучающая компьютерная программа; тестирование программного продукта; информационный и программный компонент.

\title{
THE TECHNOLOGY OF SOFTWARE PRODUCTS DEVELOPMENT FOR TEACHING FICTIONAL READING (ON THE EXAMPLE OF "ENGLISH FOR PHILOLOGISTS: ASPECT OF READING")
}

\author{
Anna S. Drach \\ senior tutor, the Department of Foreign Languages \\ Zaporizhzhia National University, Zaporizhzhia, Ukraine \\ ORCID ID 0000-0002-5086-5331 \\ annadrach2017@gmail.com
}

\begin{abstract}
The article considers the issue of educational computer program development: the stages, blocks, aspects and peculiarities. The definition of an educational computer program as a means of information and communication technologies, created for the development of skills and abilities related to foreign language competence is given taking into account the psycholinguistic patterns of reading a text, methodical approach to teaching reading fiction via information and communication technologies .

It was distinguished that educational computer program as a software for educational purposes can be offered as a system consisting of two main components: informational and software implementation. The development of educational computer programs suitable for educational institutions involves continuous interaction between the author of educational materials and the programmer. The process of creating a qualitative educational computer programme consists of certain stages: preparation of source materials; development of the programme structure of educational computer program; creation of a software product; aligning and adjustment; implementation of educational computer program; testing software product; educational computer program updating and error correction. The article describes the created educational program "English for Philologists: aspect of reading" that meets the criteria of correspondence and the criteria for evaluating computer programs for teaching foreign languages taking into account the peculiarities of digital text. The experimental introduction of the computer program «English for Philologists: aspect of reading», comparison of the average indicators of pre- and postexperimental sections in experimental groups and the growth by $12 \%$ have showed that the training for future teachers of English language reading fiction via the educational computer programme «English for Philologists: aspect of reading» has proved to be effective: all the groups have reached the required level of reading comprehension.
\end{abstract}

Keywords: educational computer program; testing software product; informational and software implementation. 


\section{REFERENCES (TRANSLATED AND TRANSLITERATED)}

[1] V. N. Akent'eva, «Process guidance of texts' comprehension according to specialty during teaching reading in non-linguistic high school ( based on the material of the English language)», dis. kand. ped. nauk, KGPIIJa, Kiev, 1986. (in Russian).

[2] N. V. Basova, Pedagogy and practical psychology. Rostov-na-Donu, Russia: Feniks, 2000. (in Russian).

[3] M. A. Bovtenko, Computer linguodidactics: [tutorial].Moscow, Russia: Flinta, 2005. (in Russian).

[4] O. Ya. Kovalenko, and I. P. Kudina, The book of a foreign language teacher: the reference and methodical edition. [iss. 2nd compl.]. Kharkiv, Ukraine: TORSINH PLIuS, 2006. (in Ukrainian).

[5] O. S. Krasovskyi, «Didactic principles of designing an electronic textbook on Natural Sciences for senior schools of general educational institutions», avtoref. dys. kand. ped. nauk, Kyiv, 2013. (inUkrainian).

[6] V. M. Kukharenko, O. V Rybalko, and N. H. Syrotenko, Distance Learning: Terms of Usage. Distance course: Tutorial. 3rd issue. Kharkiv, Ukraine: NTU «KhPI», «Torsinh», 2002. (in Ukrainian).

[7] N. I. Mulina, «Methodology of developing and using the distance course of the English language», dys. kand. ped. nauk, Kyiv, 2001. (in Ukrainian).

[8] L. N. Pogorelova, «Creation of a text in a computer environment», avtoref. dis. kand. filol. nauk, Moskva, 1993. (in Russian).

[9] S. V. Radetska, «The methodology of teaching future economists professionally oriented reading in English using a computer», dys. kand. ped. nauk, Kyiv, 2004. (in Ukrainian).

[10] A. N. Romanov, V. S. Goroncov, and D. B. Grigorovich, The technology of distance education in the system of correspondence economic education. Moscow, Russia: JuNITI - DANA, 2000. (in Russian).

[11] P. I. Serdjukov, «Theoretical bases of teaching foreign languages in a language university with the usage of information technology», dis. d-raped. nauk, Kiev, 1997. (in Russian).

[12] O. B. Bihych, and others, Theory and practice of foreign-language professional-oriented competence formation in speaking among students of non-linguistic specialties. Collectivemonograph.Kyiv, Ukraine: Vyd. tsentr KNLU, 2013. (in Ukrainian).

[13] J. Colomen, «Interactive Multimedia»,Computers as a Tool in Language Teaching. N.Y., USA: EleisHorwood,pp. 87-111, 1991.(in English).

[14] R.C.Scarcella, E.S. Anderson, and S.D. Krashen,Developing Communicative Competence in a Second Language.Boston, USA: Heinle and Heinle Publishers, a division of Wadsworth, Inc., 1990.(in English).

[15] P. Dunkel,«The Effect of CAI on ESL Reading Achievement»,CALL Digest, vol. 4(1), pp. 253-261, 1988.(in English).

[16] R.Heinich, M.Molemda, and J.D.Russel,Instructional Media and the New Technologies of Instruction. N.Y., USA: Macmillan Publishing Company, 1993.(in English).

[17] T. Hutchinson, and A. Waters,English for Specific Purposes: A Learner-Centered-Approach. Cambridge, USA: CambridgeUniversity Press, 1987.(in English).

[18] M.Simonson, and A.Thompson, Educational Computing Foundations.New-York, USA: MacMillan College Publishing Company, 1994.(in English).

[19] I.M. Hefzallah,The New Learning and Telecommunications Technologies. Their Potential. Springfield, Illinois, USA: Charles C. Thomas Publisher, 1990.(in English).

[20] Z. Voronka, «Active Methods of Teaching Spoken English»,Foreign Languages, vol. 2, pp. 3-5, 1995.(in English).

\section{(cc) BY-NC-SA}

This work is licensed under Creative Commons Attribution-NonCommercial-ShareAlike 4.0 International License. 